\title{
Alternative forms of the high-technology district: corridors, clumps, cores, campuses, subdivisions, and sites
}

\section{Citation}

Forsyth, Ann. 2014. "Alternative Forms of the High-Technology District: Corridors, Clumps, Cores, Campuses, Subdivisions, and sites." Environ. Plann. C 32 (5): 809-823. doi:10.1068/ c1267r. http://dx.doi.org/10.1068/c1267r.

\section{Published Version}

doi:10.1068/c1267r

\section{Permanent link}

http://nrs.harvard.edu/urn-3:HUL.InstRepos:16143338

\section{Terms of Use}

This article was downloaded from Harvard University's DASH repository, and is made available under the terms and conditions applicable to Open Access Policy Articles, as set forth at http:// nrs.harvard.edu/urn-3:HUL.InstRepos:dash.current.terms-of-use\#OAP

\section{Share Your Story}

The Harvard community has made this article openly available.

Please share how this access benefits you. Submit a story.

\section{Accessibility}


CONTACT PAGE:

Alternative Forms of the High TeChnology District:

Corridors, Clumps, Cores, CAMPuSES, Subdivisions, ANd Sites

2014 Environment and Planning C 32, 5: 809-823.

Dr. Ann Forsyth

Professor of Urban Planning

Harvard University

aforsyth@gsd.harvard.edu 


\title{
Alternative Forms of the High TeChnology District: Corridors, Clumps, Cores, CAMPuses, Subdivisions, ANd Sites
}

Word count: Main Paper 6513; Abstract 142

Note: All figures to be available online in color and in black and white in print.

\begin{abstract}
Does a high-tech economy create fundamentally different places to other employment areas? This paper proposes a typology of small to medium scale high technology districts in terms of their physical environments rather than their economic features (which is the more common basis of such classifications). It defines a set of recognizable high tech places: corridors, clumps, cores, comprehensive campuses, tech subdivisions, and scattered tech sites. It argues that there are many overlaps in design and layout with generic urban industrial and office development, and with planned new towns, university campuses, and garden suburbs. However, as this part of the economy grows, so too will the effect of such places on long-term urban sustainability and livability. It is important that planning and design for such developments considers larger effects on issues such as transportation options, energy use, housing balance, and sense of place.
\end{abstract}




\section{Alternative Forms of the High TeChnology District: Corridors, Clumps, Cores, CAMpuses, Subdivisions, ANd Sites}

\section{Forming High Tech Places}

The second half of the twentieth century brought a number of major world changes. Women's roles evolved; environmental damage increased; the world economy became increasingly linked through flows of money, goods, and information; and high technology industries became major economic players (Castells 1997; 2000). This latter change, emerging high tech industries, has produced a set of gadgets and modes of communication that have infiltrated most parts of the human environment. The places where people design and build these devices and programs have also become an important part of the urban landscape. Are these high-tech production environments fundamentally different places to other employment areas at the scale of the district? This paper proposes a typology of six types of small to medium scale high technology districts in terms of their physical environments rather than their economic features: corridors, clumps, cores, comprehensive campuses, tech subdivisions, and scattered tech sites.

Much attention has been focused at a broader scale of development-whether certain industries cluster in metropolitan areas or other broad regions-and on the economic organization of industrial districts. Looking though a different lens, that of physical place, this paper identifies physical types high-technology producing districts.. It argues that there are many overlaps between such environments and generic urban industrial and office development, planned new towns, university campuses, and garden suburbs. However, while not unique, as this part of the economy grows so too will the effect of such places on long-term urban sustainability and livability. How high tech development occurs physically has substantial implications for the future of urban areas. Governments seeking such development are often focused primarily on promoting economic development but should also consider urban design and larger planning implications, specifically which district design types may best enable positive long-term physical evolution of urban areas.

The paper examines these topics by first briefly exploring how economic development and innovation experts have approached the issue of place and high technology. It then outlines the physical planning typology and how such places fit within metropolitan areas that have either strong high tech concentrations or are not so endowed. It then examines the six district types. The paper concludes by reflecting on how these types matter for the future of urban form, including how physical places function for the wider population and not just those involved in high tech industries. While such districts have much in common with other types - such as office areas and specialized manufacturing - they are an important kind of district and governments aiming to attract such industries could think more about their potential for longterm physical evolution.

Innovation and High Tech Places

High technology is a broad category of work from software to hardware, from biotechnology to information technology, and from research and manufacturing to data processing. In the U.S. 
and elsewhere, different places tend to specialize in different activities (Cortright and Mayer, 2001). In terms of the physical places where high tech industries occur, Castells and Hall (1994) still provide one of the most useful overviews covering a broad range of international examples. As they explain:

There is an image of the nineteenth-century industrial economy, familiar from a hundred history textbooks; the coal mine and its neighboring iron foundry, belching forth black smoke into the sky, and illuminating the night heavens in its lurid red glare. There is a corresponding image for the new economy that has taken its place in the last years of the twentieth century, but it is only just imprinting us on our consciousness. It consists of a series of low, discrete buildings, usually displaying a certain air of quiet good taste, and set amidst impeccable landscaping in that standard real-estate cliché, a campus-like atmosphere. (Castells and Hall, 1994, 1)

The quest to foster high technology innovations has led to many ideas about how to create better environments for such innovative work. Perhaps the predominant set of such proposals or assessments have come from the field of economic development where the environment being designed is the economic, business, organizational, or regulatory environment, often at the regional scale although also including subregional areas (Castells and Hall, 1994; Markusen, 1996; Boddy, 2000; Koh et al., 2005). While such economic development happens in particular places, in such proposals or analyses the overall physical design is seen at most as a side effect of a set of economic, organizational, and governmental arrangements. The contribution of this paper is to make it a main focus.

For example Markusen (1996, 293, 298), in a now classic article, proposed that there are four types of industrial districts - the "new industrial district" with many small, locally-owned firms; "hub-and-spoke" industrial districts, dominated by a small number of large externally-oriented firms; satellite platforms, with "unconnected branch plants"; and "state-anchored" districts with "one or more public-sector institutions" such as military bases or universities. A variety of industries can take these forms-not just high technology ones--but among Markusen's examples for each of them are high tech-oriented places: Silicon Valley is a variant of the new industrial district (though it is so large it has components of all types); Boeing and Microsoft in the Seattle area are examples of a hub and spoke anchors; satellite platforms can be seen in the "unrelated research centers of major multinational corporations" (p.304) in Research Triangle Park in North Carolina and in the "better-performing technopoles" in Japan; and Japan's Tsukuba Science City, with many national research institutes, is an example of a state-anchored district. This is an important and much cited typology, and it has received some development from others in terms of innovation (Clark et al., 2009), but its analysis is economic. The types do not clearly match particular physical plans or urban designs.

Some descriptions of the relationship between place and high technology are more abstract. One current popular approach is to stress "local buzz" and "global pipelines", that is that there needs to be local level interactions and networking between firms, researchers, and the like but also access to global knowledge (Bathelt et al., 2004). Others have analyzed broad social and 
educational features attractive to a "creative class" or fostering economic growth more generally such as universities and other lifestyle amenities (review in Edgington, 2008; Florida et al., 2008; Storper and Scott, 2009). While these kinds of interactions and amenities suggest some places may be more supportive of innovation than others, there are a broad array of designs that can allow people to network or that may be attractive to the highly educated (from outdoor recreation areas to hip downtowns).

Research on innovation more generally, and not just high tech industries, provides similar broad guidance. Typically this literature proposes that innovation involves both invention of an idea and diffusion of that idea (Rogers, 1995; Ward, 2002, 4; Utterback, 1994. As Forsyth and Crewe $(2010,179)$ explain, in work on technopoles, "innovation, to many researchers in the field, requires a supportive context or environment, social networks, and a milieu in which innovation can be generated, recognized, and spread" (Csikszentmihalyi, 1996; Dacey, 1989; Rogers, 1995; Boddy, 2000; Pinch et al., 2003).

Several works have examined how designers have attempted to create physical places that can foster creativity and the transfer of new knowledge to production facilities. In terms of high end creativity, Fang and Xie (2008) describe designing a research campus where workers could partake in a set of amenities related to international preferences. Many developments designed for such creative work are in what Forsyth and Crewe (2010) call the international campus-garden-suburb style. Few are as comprehensively designed for work, housing, and recreation as the Japanese developments highlighted in their paper-including the science city of Tsukuba and the master planned Isumi Park Town. Most, however, have some features of orderly layout, shiny modern buildings, bermed site perimeters, and manicured plantings (Rankin, 2010). That is whether planned at a large scale as comprehensive, multi-use developments, or more incrementally built, they often have a similar look. Again, however, these papers looked at new developments; but there are other physical settings where innovation can occur including older settlements (Castells and Hall, 1994).

This paper draws on the literature in economic development, technology transfer, and urban design, as well as site visits to high-tech sites on four continents, to identify six distinctive town or district types of high-tech promoting environments.

Several surveys and historical works have been particularly helpful in developing this typology (Castells and Hall, 1994; Forsyth and Crewe, 2010: Wakeman, 2003). Lang et al. (2009; Lang, 2003) had identified important types of office locations: primary and secondary downtowns, urban envelopes, edge cities, edge city corridors, and edgeless cities. However, their analysis was mostly concerned with metropolitan-level distribution rather than urban design at the district scale.

In developing the typology I focused on four key dimensions. First was the location with a metropolitan area, key to accessibility and with implications for density and development period of the surrounding area. Second was the physical scale of the developments. Taking a region as a large physical scale the district types are either medium (thousands of hectares, 
sometimes tens of thousands of hectares); small (hundreds of hectares) or tiny (just a few hectares). Larger areas are likely to be more mixed use. Third was the level of overall physical planning and urban design-some types have little physical coordination and others are designed in great detail. While there may certainly be planning and design activity to create the various less planned types, such planning may be for a building complex or basic transportation infrastructure rather than a comprehensive physical design at the scale of a district, corridor, or other segment of a city. Finally, I considered the level of economic planning, though this was not as important in defining physical types.

It should be emphasized that this is a physical, urban design typology; many of these district types are similar in economic terms but what is important for this paper is that they have distinctive layouts and looks. These features in turn have implications for long-term ecological sustainability, social opportunities, and sense of place.

\section{High Technology District Types}

The six types represent the environments at the scale that people experience as they move around in their daily lives in neighborhoods, employment districts, and similar areas. For brevity I call these the "district" types:

1. Corridors expand out along a major route that may be radial or circumferential-the IT Corridor in Chennai and Route 128 in Boston are examples. They are physically distinctive in that they are linear.

2. Clumps are the classic loose concentrations of new buildings, office parks, and other facilities, sometimes in special economic zones. They may have a planned research park as a focal point. Whitefield on the edge of Bangalore in India, Sophia-Antipolis in France, and the area around Cambridge, England, are examples (Wakeman, 2003).

3. Cores include downtowns and urban university districts in larger cities; they insert high tech into an existing fabric and often benefit from adjacencies with related industries like advertising or universities. They are likely to be part of a big, region-wide cluster. Examples include SoMa in San Francisco and the Kendall Square area of Cambridge, Massachusetts (Castells and Hall, 1994).

4. Campuses are new towns, or at least large scale comprehensive communities, planned for innovation. They may take up thousands of hectares (Forsyth and Crewe, 2010). Cases include large scale science cities such as Tsukuba Science City in Japan or large mixed-use, comprehensively designed science parks. They may also include new towns or garden suburbs with a strong high tech component such as Irvine in Southern California (Forsyth, 2005).

5. Tech subdivisions are smaller developments, designed as a piece but taking up at most a hundred or so hectares, not thousands. They are built new in suburban and semi-rural sites and are typically single use areas.

6. Scattered tech sites are individual buildings not part of concentrations. Although they may be visually similar to those in the other districts, they are not planned in any coordinated way; neither do they form a spontaneous concentration such as a corridor. 
I avoided using the term "park" in the typology as it has been applied to such a wide range of developments from a few hectares to a few thousands of hectares and with widely varying levels of physical planning and mixtures of uses. The term park often indicates a specific economic character; parks are frequently described in terms of numbers of firms and employees not physical size (e.g. Koh et al., 2005; Lai and Shyu, 2005). The six types may all appear in a regional or metropolitan cluster of high tech industries - so one "cluster" may have all of them. Some of the smaller types can occur in areas without such concentrations and take advantage of communications infrastructure to link their work to the wider economy. Finally people may work as individual lone eagles outside such built areas. That is the subject of another paper.

Figure 1 outlines the features of these types more systematically, demonstrating areas of overlap and differences in terms of location, scale, physical planning, and economic planning. It is also possible to have hybrid types. That is they are more ideal types than mutually exclusive categories.

Figure 1: High Technology Environments and Features

\begin{tabular}{|c|c|c|c|c|}
\hline $\begin{array}{l}\text { Type (down); } \\
\text { features (across) }\end{array}$ & Location in metro & $\begin{array}{l}\text { Typical } \\
\text { scale }^{1}\end{array}$ & $\begin{array}{l}\text { Level of overall } \\
\text { physical planning }\end{array}$ & $\begin{array}{l}\text { Level of economic } \\
\text { planning }\end{array}$ \\
\hline Corridors & $\begin{array}{l}\text { Radial or } \\
\text { circumferential }\end{array}$ & Medium & Low to medium & Low to medium \\
\hline Clumps & $\begin{array}{l}\text { Typically middle to } \\
\text { outer suburbs }\end{array}$ & Medium & $\begin{array}{l}\text { Low to medium, may } \\
\text { have highly planned } \\
\text { components }\end{array}$ & Low to high \\
\hline Cores & Central city & $\begin{array}{l}\text { Small to } \\
\text { medium }\end{array}$ & $\begin{array}{l}\text { Low in terms of IT (the } \\
\text { core city as a whole } \\
\text { may be heavily } \\
\text { regulated) }\end{array}$ & Low to medium \\
\hline Campuses & $\begin{array}{l}\text { Middle to outer } \\
\text { suburbs }\end{array}$ & $\begin{array}{l}\text { Small to } \\
\text { Medium }\end{array}$ & High & Medium to high \\
\hline $\begin{array}{l}\text { Technology } \\
\text { subdivision }\end{array}$ & $\begin{array}{l}\text { Typically middle to } \\
\text { outer suburbs; may } \\
\text { include core areas }\end{array}$ & Small & Medium to high & $\begin{array}{l}\text { Low (an } \\
\text { opportunistic } \\
\text { private park) to } \\
\text { high }\end{array}$ \\
\hline Scattered Sites & $\begin{array}{l}\text { Anywhere-from } \\
\text { core city to rural but } \\
\text { many in suburban } \\
\text { areas }\end{array}$ & Tiny & Varies & Varies \\
\hline
\end{tabular}

Draws on: Castells and Hall, 1994; Forsyth and Crewe, 2010

1. Medium environments are 1,000s or even 10,000s of hectares; small are 100s of hectares; tiny are a few hectares. A regional cluster would be large. 
How Districts Fit in Clusters

This discussion has focused on physical districts and sites at scales below the metropolitan area; and earlier economically-based classifications about how industries relate to place. It is important to also deal with one more type-the regional scale cluster (or the lack of it). I use the term regional-scale cluster because the literature is quite unclear about just how big a cluster needs to be and they seem to come in sizes from part of a city upward (Martin and Sunley, 2003). Such clusters are at their base an economic category, related to a concentration in certain industries, although the concentration of industry does have physical effects. As Porter (1998) describes:

Clusters are geographic concentrations of interconnected companies and institutions in a particular field. Clusters encompass an array of linked industries and other entities important to competition. They include, for example, suppliers of specialized inputs such as components, machinery, and services, and providers of specialized infrastructure. Clusters also often extend downstream to channels and customers and laterally to manufacturers of complementary products and to companies in industries related by skills, technologies, or common inputs. Finally, many clusters include governmental and other institutions - such as universities, standards-setting agencies, think tanks, vocational training providers, and trade associations - that provide specialized training, education, information, research, and technical support. (Porter, 1998, 78)

Regional clusters include Hollywood (Southern California) and the wine cluster in Northern California (Porter, 1998). Silicon Valley is the most well-known such technology cluster-and is unusual because of its strength in multiple industries. Many places around the world have tried to copy it in some way, though at different scales and not always emphasizing multiple types of technology development (Boddy, 2000; Cortright and Mayer, 2001; Bresnahan and Gambardella, 2004).

Historical, case-study, and insider accounts of high tech innovation illustrate the extensive personnel mobility between firms in many high tech areas and the need for varied funding sources (Moore and Davis, 2004; Porter, 1998). Regional-scale clusters support those needs through both public and private sector activities (Bass, 1998; Park, 2001; Mangematin and Errabi, 2012).

What of the physical forms of high tech areas in clusters? In terms of spatial distribution, clusters may include basically all the district- level types dealt with in this paper (see figure 2). Larger and denser clusters have a lot of high tech activity although such activities may be only really visible in some parts of the cluster. That is a cluster is an economic concentration with complicated physical outcomes. It may have many types of the districts dealt with in this paper or just a few; clusters also evolve over time. In addition, even places without a high concentration of high technology may have some such high-tech district environments. That is an economic analysis of clusters may not say much at all about the physical places. However, physical places are important for people's daily experiences, for urban public finance (are they 
easy or difficult to service?), and for long term sustainability of a region (do they foster social equity, energy efficiency, preservation of natural resources, and good long-term jobs?). In the next part of the paper I examine the district types in these terms.

\section{Figure 2: Conceptual Plan of Metropolitan Region and District types}

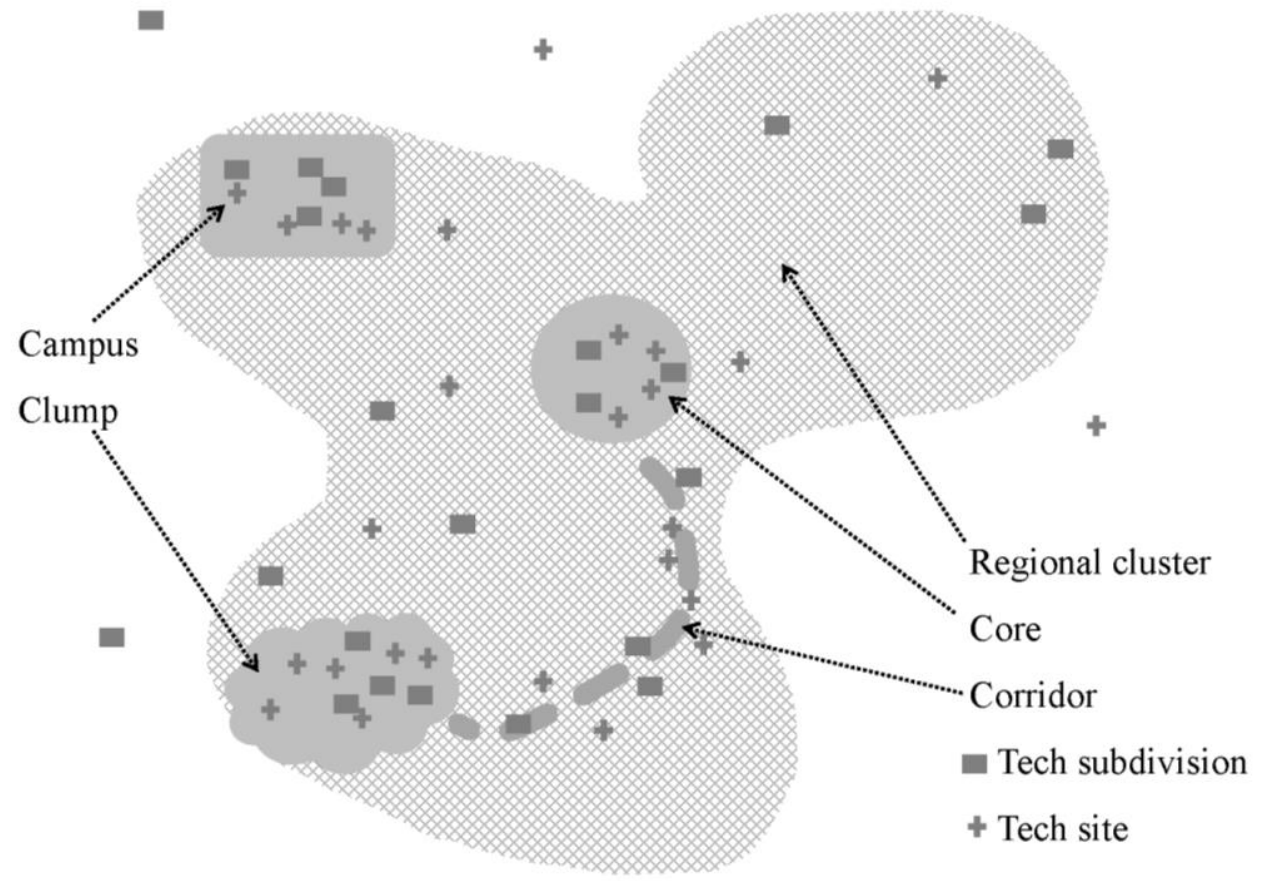

\section{District Types}

\section{Corridors}

Corridors grow up along a major road possibly also supporting transit service. Economically they are a concentration of activity within a metropolitan cluster, but physically, they are distinctive. The main road itself is likely primarily for access, a major freeway or divided road. The IT Corridor (Rajiv Gandhi Salai) south of Chennai is a wide toll road but like many Indian roads the shoulders are unformed; so a shiny PayPal building is reached across a muddy verge. In this corridor large IT facilities are typically walled. Much care is given to the facilities inside the boundaries and the area outside is less cared for. However, these fairly unfinished roads are much used by people getting around (see figure 3 ). 
Figure 3: Larger District Types: Corridors, Clumps, Cores, and Campuses

\section{Corridors}

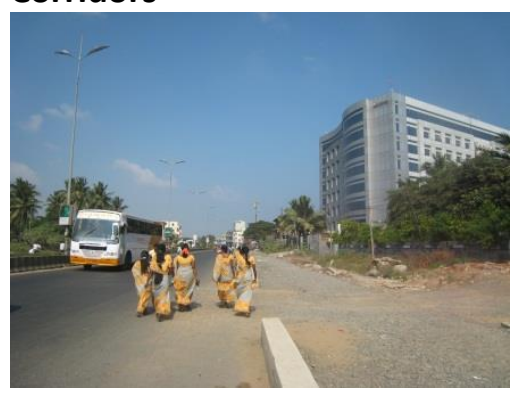

IT Corridor, Chennai

\section{Clumps}

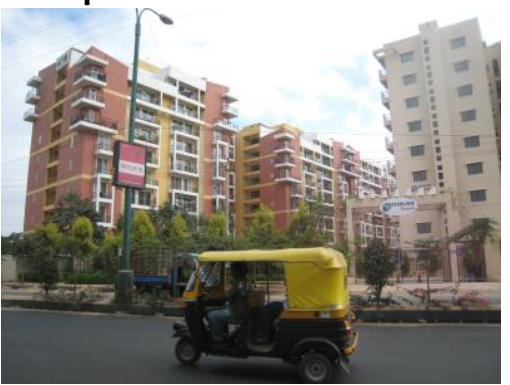

In Whitefield, Bangalore

\section{Cores}

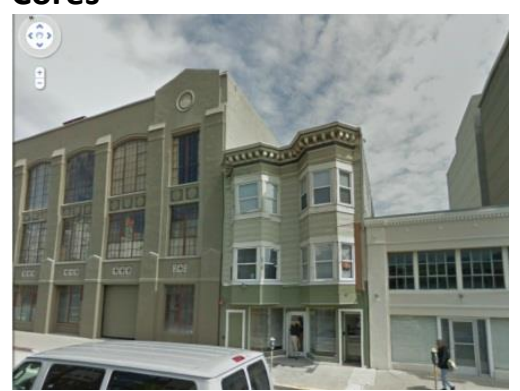

San Francisco, SoMa Area

(Google Streetview)

\section{Comprehensive Campuses}

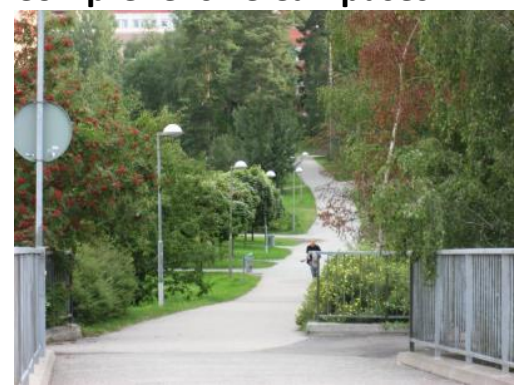

Kista, Sweden

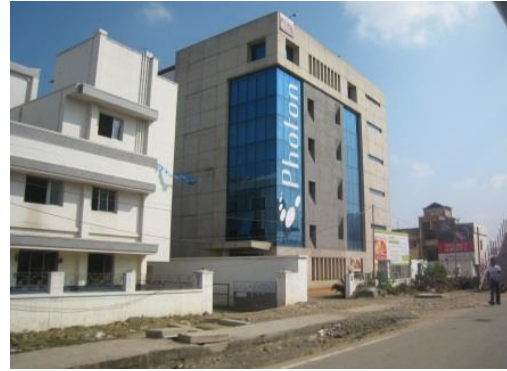

IT Corridor, Chennai

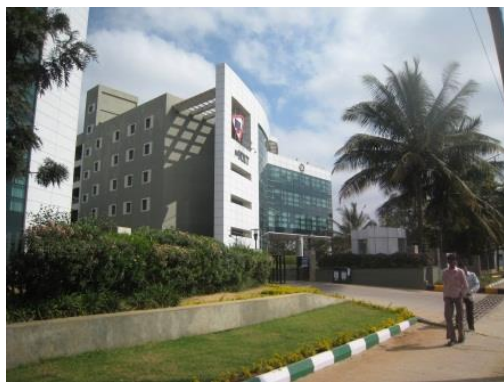

Whitefield, a major node in the Bangalore cluster

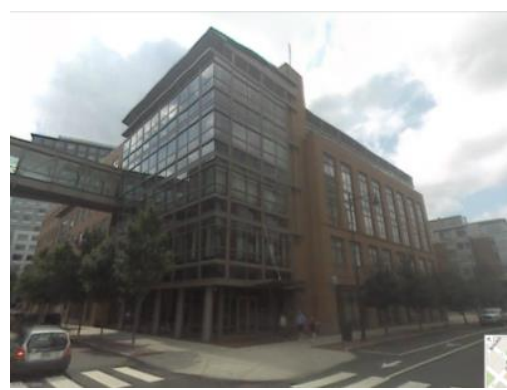

MIT University Park Areas

(Google Streetview)

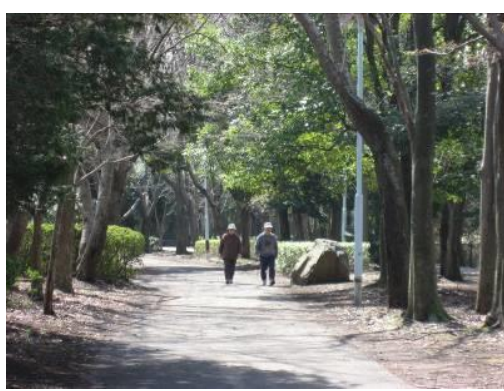

Tsukuba, Japan

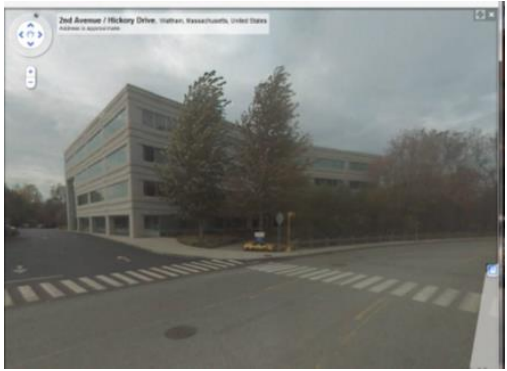

Route 128 area Westwood MA (Google Streetview)

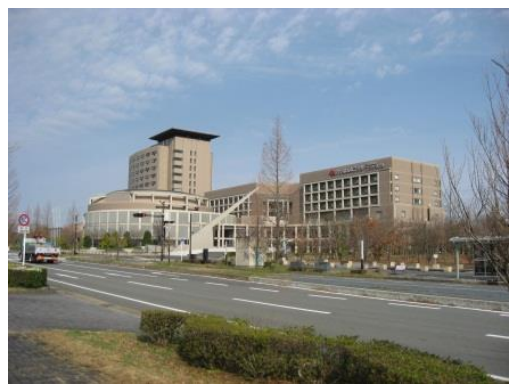

One of the main facilities in Kansai Science City in Japan a more heavily planned cluster

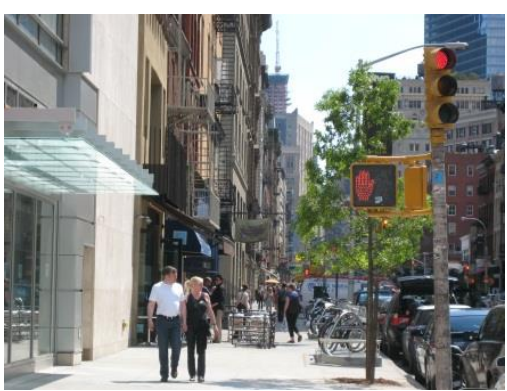

Manhattan around Silicon Alley

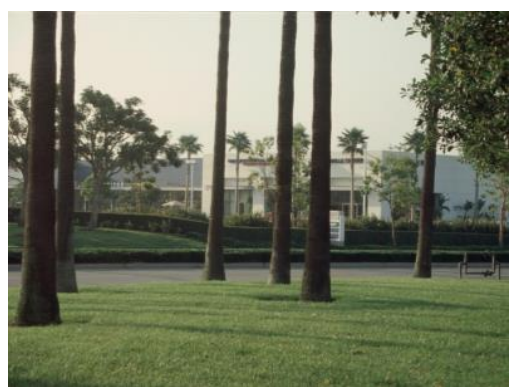

Irvine, USA

All photos by author except where noted. 
Even in areas where the physical infrastructure is more developed than Chennai, however, roads are likely to be primarily access-points, not designed public places. Limited access highways such as route 128 near Boston are examples.

Visually these developments demonstrate order through the continuity of the main road(s) and the similar boxy buildings set in landscaped parcels. But there is also a level of chaos or disorganization. Traveling along a street, or examining aerial photography of the corridor, it is apparent that high tech businesses are spread out along the road and not at all continuous. High tech parcels or parks with a broadly international campus-garden-suburb appearance are interspersed with other developments from retail to housing. This is a mixture of uses that has great potential in the long term in terms of creating multi-functional places. However, in the present different uses are often primarily linked by motorized modes with pedestrian and cycling infrastructure more discontinuous or informal. They typically lack continuous sidewalks or pedestrian-scaled street lighting, for example. While they may be used by pedestrians in locations such as India, this is not a designed use. Similarly, housing may cater for some parts of the high tech economy (the more affluent) and not others.

\section{Clumps}

Clumps are a non-linear version of a corridor. Absent the transportation route as an organizing principle they typically have some sort of overall physical and economic coordination. This may be modest-- a government puts in roads; buildings are likely regulated. A local government may provide economic incentives or government contracts (e.g. for defense or telecommunications). They may even be created by higher level (state or national) governments designating a special economic zone or a large industrial park (in the thousands of hectares). But overall most clumps, even ones developed with government incentives, are built incrementally, one parcel or technology subdivision at a time. They may be mixed in with housing and retail but this has not been developed according to a comprehensive vision.

Some are coordinated at a regional level in terms of their economic character. Kansai Science City in Japan is a public-private joint venture located in a15,000 hectare triangle between Kyoto, Osaka, and Nara and with a network of technology parks or subdivisions coordinated by a public private partnership (About Kansai Science City, 2009; Kansai Science, 2010). While Forsyth and Crewe $(2010,177)$ propose it is a campus - garden suburb, and it has network of manicured landscaped areas including paths and parks, it is a science economic zone than a free-standing science city (Forsyth and Crewe, 2010, 177; see also Wakefield, 2003).

Such developments can be identified visually. They often have a name and may have some anchor buildings such as key firms, conference facilities, or shopping centers. These are not comprehensively designed in a physical sense, however, and like corridors they are discontinuous. They include housing and retail but uses are often sited opportunistically, and it may not be easy for people to get around. Transportation may be primarily based on motorized transportation. In countries where there is more overall planning they will likely be better coordinated, but as the impetus comes from economic development, physical design and 
planning attention may be most focused on specific sites, and on the road network, not any overall idea of coordinated appearance, nonmotorized transportation, or housing provision. Whitefield outside Bangalore, pictured in Figure 3, is an example (Also Valler et al., 2012)..

\section{Cores}

Cores are small concentrations of high tech development in the centers of bigger cities. For example, Edgington (2008) describes a private research park in the central district of Kyotothe only one in Japan. Established in 1988, and developed by the Osaka Gas Corporation, 20 years later it was home to approximately 240 companies many in new media and information technology (Edgington, 2008, 412). In this case, as in the University Park in the Kendall Square area near MIT, or redeveloped areas in central San Francisco, many of the buildings are new (Graham and Guy, 2002). However, in other cases high tech companies adapt existing buildings, renovating warehouse and older commercial buildings. Government may also take a lead in coordinating redevelopment (Cassellas, 2011).

Again, these core areas may be very similar economically to an outer clump or corridor. However, visually they have a distinctive identity defined by fitting into an existing street pattern. They may use new buildings, even groups of them, but typically on a smaller footprint, necessitating building up. Many do not alter the overall built form of the city and may be primarily visible through signage; the outsides look much like other office or light industrial buildings. They will likely be mixed in with many other businesses. Transportation varies by city but urban cores typically have better public transportation links than elsewhere in the metropolis. Housing, while often close, may however be either expensive or run down. Overall, cores have often already been redeveloped several times, contain a mixture of uses, and can be expected to be resilient. However, because high-tech companies and workers can frequently outbid local businesses and residences, there may be significant displacement of existing lowerincome occupants (Graham and Guy, 2002).

\section{Campuses}

Forsyth and Crewe (2010) outline how some purpose-built high-technology developments have adapted the campus and garden city or planned garden suburb model into what they call the international campus-garden-suburb style (Gumprecht, 2005; O'Mara, 2005). True science cities, planned from the beginning for high tech development, are comprehensively developed with housing and business areas. They vary in scale from the very large (e.g. Tsukuba, population planned for 200,000 ) to the medium e.g. Kista planned for far fewer (Forsyth and Crewe, 2010; 2009; Baringa and Ramfelt, 2004). Some comprehensively planned mixed-use developments were not intended initially for high tech but attracted a great deal, for example Izumi Park Town outside Sendai (benefitting from the Japanese Technopolis program) or Irvine in Southern California (Forsyth, 2002). Some are less comprehensively designed and take the form of a coordinated campus with an overall planning framework dealing with issues such as transportation, with key nodes being designed in the campus style. Kansai Science City, described above, in the clumps section is one example. It is a kind of hybrid of the two typescampus and clump. 
Of course this campus look is featured in many of the other types, in larger and smaller chunks. The comprehensive campus is distinctive, however, in several ways. Such environments are highly planned from the start for a variety of uses so people can live and work in an integrated environment. They draw on traditions of both self-contained garden cities and university campuses. They contain extensive open spaces. They are also large, meaning that their orderly and comfortable environments extend continuously over a large area, typically in a suburban setting (Forsyth and Crewe, 2010). This is a distinctively different type of environment to that of a corridor or clump; in those other cases highly designed parcels and research parks are interspersed with more incremental developments.

\section{Tech Subdivisions}

Tech subdivisions are smaller campuses, less comprehensive than the prior group, mainly containing businesses and not explicitly coordinating with housing and transportation at a large scale. I use the term subdivision to designate areas of up to a few hundred hectares, not a few thousand. Larger areas fall in other categories. As stated earlier I avoided the term tech park because literature uses "parks" much more widely. Tech subdivisions are an important physical design worth distinguishing from these large economic zones.

One case is the Shenzhen Silicon Peak Software Ecological Park examined by Fang and Xie (2008). This 136 ha high technology subdivision developed in the 2000s, sported a design philosophy focused on: people, resources, economy, environment, ecosystem, technology, and society. Fang and Xie $(208,114)$ explain how designers hoped their landscape design could achieve aesthetic and ecological goals such as microclimate control, visual buffering, and protecting natural features. But their environmental goals also aimed to attract high tech workers. As they describe, they wanted to create:

...a relaxing working environment, which provides a comfortable and high-standard living environment; creates an open atmosphere promoting innovation and adventure and tolerating failure for talented, well-trained, and highly mobile staff; and ensures that they have favorable business treatments and work efficiently...[T]he hi-tech park offers the staff higher quality services and [a] more congenial recreational environment than the city. Citizens who have huge wealth and abundant recreation time can find themselves havens and cozy homes. (Fang and Xie, 2008, 103)

While the example above demonstrates a high level of design attention, other tech subdivisions are more modest. They may be found as components of the prior four types but are dealt with separately here because they may also appear in areas without such larger concentrations of technology companies, both in urban and rural settings. Valler and Phelps (2011) identify a number of science parks taking this character in semirural parts of South East England with a number of such subdivisions or "camps" in close proximity forming Science Vale, UK.

In general, because of their small size they piggyback onto existing, or incrementally developed, infrastructure. They may be in well serviced areas or quite isolated; housing may be close or at some distance. These are very flexible building blocks of a high tech environment. 


\section{Scattered Sites}

Scattered sites are individual technology buildings or smaller research parks of a few hectares that may be scatted throughout a metropolitan area or found in clumps and corridors. These meet the need for industrial and high tech office space using existing, or incrementally developed, infrastructure. They are often the high tech equivalent of office sprawl, actually taking advantage of new communications and logistics capabilities to link to other parts of the high tech economy (Crane and Chatman, 2003).

\section{Why Does this Matter?}

Postsuburbia or Diverse Suburbia?

This paper has proposed a typology of high technology environments and examined how they differ from other employment areas. I examined the question: does a high-tech economy create fundamentally different kinds of places? It argues that in urban design terms high tech districts are not fundamentally different to other employment areas that either employ knowledge workers or engage in precision manufacturing. However, they do have a somewhat predictable character, at the site, technology subdivision, campus, core, clump, or corridor scale. Because many high tech companies, and local governments and developers hoping to attract them, use a similar aesthetic one might have an overall impression of low shiny buildings, large berms with monument signs, and tastefully designed security guard shelters (Forsyth and Crewe, 2010). Many have at least some international companies, so one might see General Electric signage on a building in Bangalore or find an Adobe building in Noida (a suburb of Delhi). Even cores, while often featuring historic buildings, may also include new downtown tech subdivisions and scattered site developments that feature shiny buildings, obvious signage, and elegant landscaping.

Such environments are often the subject of the literature on postsuburbia. For those who see suburbs as essentially residential, new terms are needed for environments that include substantial jobs. This is not a new problem. Earlier in the twentieth century authors created terms such as suburbs of production, suburban satellites, and industrial suburbs as a way of capturing early forms of the non-residential suburb; postsuburbia indicates the latest round of such discussions (Douglass 1925, 74-92; Schnore 1957; Berger 1960). Such economic activity was the result of both private investment and government programs (Malecki, 1982; Scott, 1993; Forsyth, 2002; O’Mara, 2005).

High technology has also been an interest of suburban scholars for some decades. Fishman (1987) coined the term "technoburb" to describe a new kind of suburb, though in this case one enabled by new technologies, not necessarily producing them (also van Geenhuizen and Nijkamp, 2007). A technoburb is:

A peripheral zone, perhaps as large as a county, that has emerged as a viable socioeconomic unit. Spread out along its highway and growth corridors are shopping malls, industrial parks, campus-like office complexes, hospitals, schools, and a full range of housing types. Its residents look to their immediate surroundings rather than to the 
city for the jobs and other needs; and its industries find not only the employees they need but also the specialized services.

... In most technoburbs [high tech] industries make up only a small minority of jobs, but the very existence of the decentralized city is made possible only through the advanced communications technology which has so completely superseded the face-to-face contact of the traditional city. The technoburb has generated urban diversity without traditional urban concentration. (Fishman, 1987, 184)

Not all work on postsuburbia focused on industry and employment, but may rather deal with a growing cosmopolitan flavor in suburban areas or a better mix of housing and work (Lang et al., 2005; Phelps and Wood 2011). For those defining suburbs by their location in the metropolis rather than residential character, and therefore less concerned about the term "postsuburban", these debates still contribute a focus on suburban employment areas (Forsyth, 2012). High technology has both enabled general deconcentration but also provided distinctive, if hardly unique, environments.

\section{Future Evolution?}

But what of the future design evolution of specifically high tech developments? What happens when the needs of industry change or when a high tech cluster fails to take hold in an area? This is important because high technology is a growth industry and places will develop to accommodate it. However, such development is often driven by economic interests with relatively little concern about the character of the place, and particularly how such places may evolve over time. It turns out that not all of these district types are equivalent. Some patterns are more or less sustainable; leave more to chance in terms of coordinating jobs, transportation, and housing; or provide different qualities of public spaces.

Figure 4 assesses some of the potential for places to evolve. Some aspects of the environment are relatively easy to change in the medium-term. For example, industrial and research buildings are typically designed to last for decades, rather than centuries, and can be replaced. However, once land is subdivided and sold, and roads put in, the overall street pattern is much harder to alter. Some developers hold on to large parcels and only lease buildings; some governments are proactive about taking and consolidating land; but this is the exception rather than the rule. Houses are replaced less frequently than buildings used for business, so residential areas may be more complex to redevelop (Nelson, 2004). 
Figure 6: Potential Evolution of Places over Time

\begin{tabular}{|c|c|c|c|}
\hline $\begin{array}{l}\text { Type of } \\
\text { environment } \\
\text { (down) and } \\
\text { features } \\
\text { (across) }\end{array}$ & $\begin{array}{l}\text { Location in } \\
\text { metro }\end{array}$ & Potential for positive evolution & Potential problems over time \\
\hline Corridors & $\begin{array}{l}\text { Radial or } \\
\text { circumferential }\end{array}$ & $\begin{array}{l}\text { The transportation spine } \\
\text { provides a strong ordering } \\
\text { element and can be } \\
\text { redeveloped over time for } \\
\text { multiple transportation modes, } \\
\text { potentially with a series of } \\
\text { vibrant mini-cores; the linear } \\
\text { city is a model with a long } \\
\text { tradition }\end{array}$ & $\begin{array}{l}\text { Creating concentrated areas } \\
\text { (activity centers) may be } \\
\text { difficult given that the original } \\
\text { street pattern and parcel layout } \\
\text { is focused on large individual } \\
\text { parcels, fairly homogenous } \\
\text { housing, and commercial } \\
\text { enclaves }\end{array}$ \\
\hline Clumps & $\begin{array}{l}\text { Typically middle } \\
\text { to outer suburbs }\end{array}$ & $\begin{array}{l}\text { Their mixed uses have the } \\
\text { ingredients of a } \\
\text { comprehensive, sustainable } \\
\text { design; economic activity } \\
\text { provides local tax base for } \\
\text { improvements }\end{array}$ & $\begin{array}{l}\text { Their lack of overall } \\
\text { coordination may make it } \\
\text { difficult to provide transit, } \\
\text { housing, public spaces, and } \\
\text { other infrastructure in a way } \\
\text { that fits sustainable city models }\end{array}$ \\
\hline Cores & Central city & $\begin{array}{l}\text { They have typically already } \\
\text { evolved over time and can do } \\
\text { so again; have a variety of } \\
\text { buildings types and ages, as } \\
\text { well as public spaces }\end{array}$ & $\begin{array}{l}\text { Infrastructure may be aging and } \\
\text { will require investment. } \\
\text { Successful cores can be very } \\
\text { expensive, meaning that } \\
\text { housing options are limited }\end{array}$ \\
\hline Campuses & $\begin{array}{l}\text { Middle to outer } \\
\text { suburbs }\end{array}$ & $\begin{array}{l}\text { Campus mixed uses and } \\
\text { coordinated transport allow } \\
\text { intensification over time; } \\
\text { typically provide ample, well- } \\
\text { designed common spaces and } \\
\text { a balance of housing } \\
\text { opportunities }\end{array}$ & $\begin{array}{l}\text { Designs may be highly regulated } \\
\text { making it difficult to adapt to } \\
\text { changing circumstances. May } \\
\text { not offer housing for the high or } \\
\text { low end of the market }\end{array}$ \\
\hline $\begin{array}{l}\text { Technology } \\
\text { subdivisions }\end{array}$ & $\begin{array}{l}\text { Typically middle } \\
\text { to outer } \\
\text { suburbs; may } \\
\text { include core } \\
\text { areas }\end{array}$ & Small, adaptable for infill & $\begin{array}{l}\text { Can be scattered and } \\
\text { inaccessible. May be difficult to } \\
\text { link to the rest of the metropolis } \\
\text { by anything other than private } \\
\text { vehicles }\end{array}$ \\
\hline $\begin{array}{l}\text { Scattered } \\
\text { Sites }\end{array}$ & $\begin{array}{l}\text { Anywhere- } \\
\text { from core city to } \\
\text { rural but many } \\
\text { in suburban } \\
\text { areas }\end{array}$ & $\begin{array}{l}\text { Building-scale renovation } \\
\text { possible }\end{array}$ & $\begin{array}{l}\text { Can be scattered and } \\
\text { inaccessible, a contributor to } \\
\text { sprawl }\end{array}$ \\
\hline
\end{tabular}


There is not a single model for the sustainable future, of course, even looking at only one dimension such as natural systems (Crewe and Forsyth, 2011; Calle-Vasas et al., 2011). Among planners, however, the idea of the compact city, or ecocity, has received great traction. This concentrates development and mixes uses together making efficient use of urban infrastructure, making public transit service viable, allowing a diverse population to live in relatively close proximity, and saving land on the outskirts of cities (Jabareen, 2006; Calthorpe and Fulton, 2001; Newman and Kenworthy, 2000; Dunham-Jones and Williamson, 2009). The overall metropolitan area is focused on a series of walkable, transit-oriented centers. Some of the claims are disputed but this is a widely-held vision (Neuman, 2005). An alternative is the low-density ecoburb that brings people close to nature, allows on site infiltration of water, and may allow on-site energy production for buildings. This is a desirable environment for many and landscape architects have created important models. Low densities, however, mean that transportation is often via the automobile and energy use may be higher for transportation (Berke, 2008; Corbett and Corbett, 2000).

Some of these high tech districts may be able to conform to the compact city idea over time (see figure 4). Locations like Kista, a planned transit-oriented suburb (campus) in Stockholm and a high tech center, already take this form. Many clumps and corridors have substantial medium and high rise housing. In addition, urban cores are typically well serviced and have generally supported several waves of industrial evolution already. They are capable of doing this again as long as there are resources for such renewal given aging infrastructure and perhaps a lack of housing. But for other district types it will be more of a challenge to evolve to an ecocity model due to location away from infrastructure and existing development, as well as initial designs that separate land uses. While there is often open space in high tech districts it is not always optimally located for intensifying activities. It may be difficulty to add housing and shops to areas initially dominated by employment because there are not parcels of the right dimensions with adequate access, for example. 
Figure 4: Examples of Potential for Evolution as Ecocities and Ecoburbs
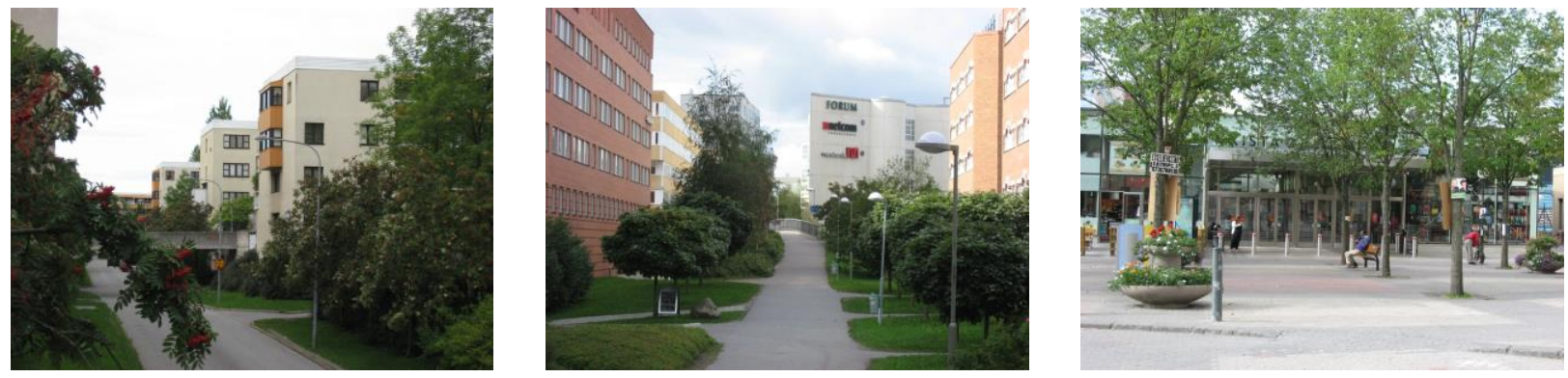

Kista: Potential eco-city: Kista is a highly coordinated planned suburb of Stockholm already demonstrating high density, transit-oriented, mixed use designs favored by many planners as an option for redevelopment.
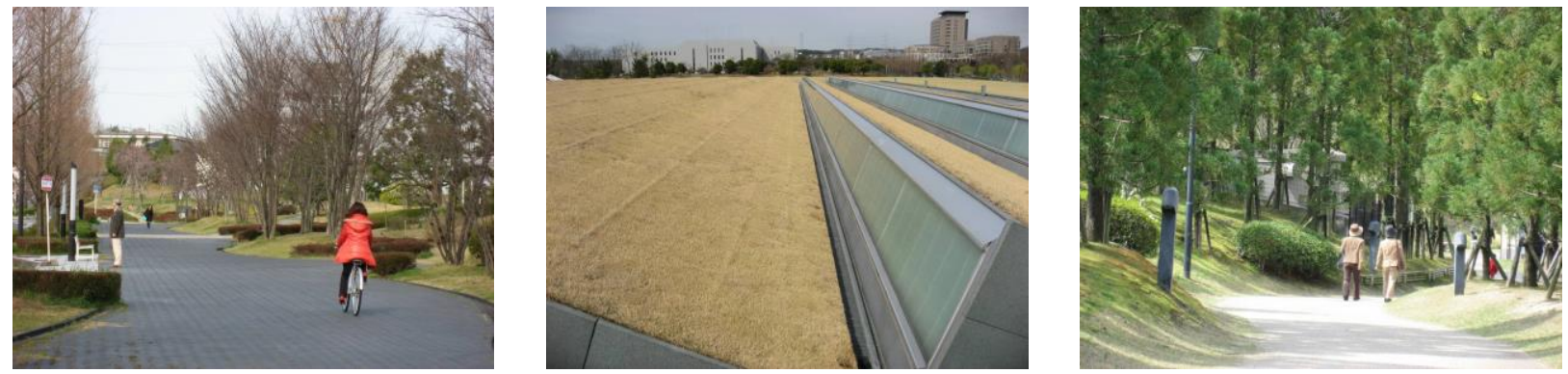

Kansai Science City: Potential eco-burb: Kansai Science City already has a low-rise environment with elements such as wide pedestrian bicycle paths, connected green spaces, green roofs, and low rise homes and industrial buildings.

Photos by the author.

Alternatively other areas may be able to be redeveloped as low-density ecoburbs bringing people on contact with nature in a decentralized vision of the good city. Where they are producing services and software rather than things, so that sales may be made over the internet, this may have few enough consequences in terms of energy used in transportation (Crewe and Forsyth 2011). This would take advantage of the existing landscaping and open space to increase habitat, water infiltration, food production, and on-site energy generation. However, in both types of development-ecocities or ecoburbs--very successful high tech districts may become so expensive that it is hard to provide housing for lower income workers. Children may not be well accommodated. It is important that planning and design considers such longer term redevelopment including effects on issues such as transportation options, housing balance, and sense of place.

Overall while not unique as places there is a predictability in the character of environments for high tech industry, reflecting the generic needs of research and manufacturing as well as the expectations and aspirations of a global workforce and businesses. While most attention has been placed on their economic character, the current experience and future evolution of urban 
areas depends at least in part on their physical form. Designing places that can be adaptable over time is a key challenge for the coming decades. 


\section{References}

About Kansai Science City download, 2009, "Kansai science city portal site" http://www.krip.jp/english/keihanna.pdf

Baringa E, Ramfelt L, 2004, "Kista: the two sides of the network society" Networks and Communications Studies 18 225-244

Bathelt H, Malmberg A, Maskell P, 2004, “Clusters and knowledge: Local buzz, global pipelines and the process of knowledge creation" Progress in Human Geography 28 31-56

Bass S, 1998, "Japanese research parks: National policy and local development" Regional Studies 32 391-403,

Berger B, 1960, Working-Class Suburb: A Study of Auto Workers in Suburbia (Berkeley: University of California Press)

Berke, PR, 2008, "The evolution of green community planning, scholarship, and practice" Journal of the American Planning Association 74 393-407

Boddy M, 2000, "Technology, innovation, and regional economic development in the state of Victoria" Environment and Planning C 18 301-319

Bresnahan T, Gambardella A, 2004, Introduction, In Bresnahan T, Gambardella A, eds, Building High-Tech Clusters: Silicon Valley and Beyond (Cambridge, UK: Cambridge University Press)

Calthorpe P, Fulton W, 2001, The Regional City: New Urbanism and the End of Sprawl (Washington, DC: Island Press)

Cassellas A, 2011, Collaborative approaches to innovation and urban regeneration: the science parks of Barcelona Metropolitan Region, Paper presented at Science and the City, Science and Technology Policy Institute, Seoul, Korea, October

Castells M, Hall P, 1994, Technopoles of the World, (London: Routledge)

Castells M, 2000, The Rise of the Network Society, Second Edition (Oxford: Blackwell)

Castells M, 1997, The Power of Identity (Malden: Blackwell)

Clark, J, Huang HI, Walsh JP, 2009, "A typology of innovation districts: What it means for regional resilience" Paper presented at Industry Studies Association Conference, Chicago: http://www.industrystudies.pitt.edu/chicago09/docs/Clark\%201.6.pdf

Corbett J, Corbett M, 2000, Designing Sustainable Communities: Learning from Village Homes (Washington, DC: Island Press)

Cortright J, Mayer H, 2001, "High tech specialization: A comparison of high technology centers," (Washington, DC: The Brookings Institution)

Crane R, Chatman D, 2003, "As jobs sprawl, whither the commute?" Access 23 14-19

Crewe K, Forsyth A, 2011, "Compactness and Connection in Environmental Design: Insights from Ecoburbs and Ecocities for Design with Nature" Environment and Planning B 38 267-288

Csikszentmihalyi M, 1996, Creativity: Flow and the Psychology of Discovery and Invention (New York: Harper Collins)

Dacey J, 1989, Fundamentals of Creative Thinking (Lexington, Massachusetts: Lexington Books)

Douglass H, 1925, The Suburban Trend (New York: The Century Company)

Dunham-Jones E, Williamson J, 2009, Retrofitting Suburbia (New York: Wiley) 
Edgington D, 2008, "The Kyoto research park and innovation in Japanese cities" Urban Geography 29 411-454

Fang C, Xie Y, 2008, "Site planning and guiding principles of hi-tech parks in China: Shenzhen as a case study" Environment and Planning B 35 100-121

Fishman R, 1987, Bourgeois Utopias: The Rise and Fall of Suburbia (New York: Basic Books)

Florida R, Mellander C, Stolarick K, 2008, "Inside the black box of regional developmenthuman capital, the creative class and tolerance" Journal of Economic Geography 8 615650

Forsyth A, 2002, "Who built Irvine? Private planning and the federal government" Urban Studies 39 2507-2530

Forsyth A, 2005, Reforming Suburbia, Berkeley: University of California Press

Forsyth A, 2012, "Defining suburbs" Journal of Planning Literature 27 270-281

Forsyth A, Crewe K, 2009, "A typology of comprehensive designed communities since the Second World War, Landscape Journal 27 56-78

Forsyth A, Crewe K, 2010, "Suburban technopoles as places: the international campus-gardensuburb style" Urban Design International 15 165-182

Graham S, Guy S, 2002, "Digital space meets urban place: sociotechnologies of urban restructuring in downtown San Francisco" City 6 669-382

Gumprecht B, 2005, "The campus as a public space in the American college town" Journal of Historical Geography 33 72-103,

Jabareen YR, 2006, "Sustainable urban forms: their typologies, models, and concepts" Journal of Planning Education and Research 26 38-52

Kansai Science City Construction Promotion Office, 2010, "General view of Kansai Science City" http://www .mlit.go.jp/crd/daisei/daikan/gaiyo_e.htm

Koh FCC, Koh WTH, Tschang FT, 2005, "An analytical framework for science parks and technology districts with an application to Singapore" Journal of Business Venturing 20 217-239

Lai, HC, Shu JZ, 2005, "A comparison of innovation capacity at science parks across the Taiwan Strait: The case of Zhanjiang High-Tech Park and Hsinchu Science-based Industrial Park" Technovation 25 805-813

Lang RE, 2003, Edgeless Cities: Exploring the Elusive Metropolis, (Washington DC: Brookings Institution Press)

Lang RE, Blakely E, Gough MZ, 2005, "Keys to the new metropolis: America's big, fast-growing suburban counties" Journal of the American Planning Association 71 381-391

Lang RE, Sanchez TW, Oner AC, 2009, "Beyond edge city: office geography in the new metropolis" Urban Geography 30 726-755

Link AL, Scott JT, 2003, "U.S, science parks: the diffusion of an innovation and its effects on the academic missions of universities" International Journal of Industrial Organization 21 1323-1356

Malecki E, 1982, "Federal R and D spending in the United States of America: some impacts on metropolitan economics" Regional Studies 16 19-35

Mangematin V, Errabi K, 2012, "The determinants of science-based cluster growth: the case of nanotechnology" Environment and Planning C 30 128-146 
Markusen A, 1996, "Sticky places in slippery place: A typology of industrial districts" Economic Geography 72 293-313

Martin R, Sunley P, 2003, "Deconstructing clusters: chaotic concept or policy panacea?" Economic Geography 3 5-35

Moore G, Davis K, 2004, "Learning the Silicon Valley Way", In Bresnahan T, Gambardella A, eds, Building High-Tech Clusters: Silicon Valley and Beyond (Cambridge, UK: Cambridge University Press)

Nelson, A, 2004, Toward a new metropolis. (Washington, DC: The Brookings Institution) http://www.brookings.edu/reports/2004/12metropolitanpolicy nelson.aspx

Neuman M, 2005, "The compact city fallacy" Journal of Planning Education and Research 2511 26

Newman P, Kenworthy J, 2000, Sustainable Cities (Washington, DC: Island Press)

O'Mara MP, 2005, Cities of Knowledge (Princeton: Princeton University Press)

Park SC, 2001, "Globalisation and local innovation system: the implementation of government policies to the formation of science parks in Japan" Al and Society 15 263-279

Phelps NA, Wood AM, 2011, "The new post-suburban politics?" Urban Studies 48 2591-2610

Pinch S, Henry N, Jenkins M, Tallman S, 2003, "From 'industrial districts' to 'knowledge clusters: a model of knowledge dissemination and competitive advantage in industrial agglomerations" Journal of Economic Geography 3 373-388

Porter ME, 1998, "Clusters and the new economics of competition" Harvard Business Review November-December 77-90

Rankin WT, 2010, "The epistemology of the suburbs: knowledge, production, and corporate laboratory design", Critical Inquiry 36 771-806

Renski H, 2009, "A new era of federal involvement in regional economic development? The case of the WIRED initiative" Environment and Planning C 27: 593-611

Rogers E, 1995, Diffusion of Innovations (New York: Free Press)

Schnore L, 1957, Satellites and suburbs, Social Forces 36 121-127

Scott A, 1993, Technopolis: High-Technology Industry and Regional Development in Southern California (Berkeley: University of California Press)

Storper M, Scott A, 2009 "Rethinking human capital, creativity, and urban growth "Journal of Economic Geography 9 147-167

Utterback JM, 1994, Mastering the Dynamics of Innovation (Boston, MA: Harvard Business School Press)

Vall-Casas P, Koschinsky K, Mendoza C, 2011, "Retrofitting suburbia through pre-urban patterns: Introducing a European perspective" Urban Design International 16 171-187

Valler D, Phelps N, 2011, "Big science and small villages: understanding the context and constraints on high-tech growth in South East England" Paper presented at Science and the City, Science and Technology Policy Institute, Seoul, Korea, October

Valler D, Phelps N, Wood A, 2012, "Planning for growth: the implications of localism for 'Science Vale,' Oxfordshire, UK" Town Planning Review 83 457-487

Van Geenhuizen M, Nijkamp P, 2007, "Cities and footlooseness: in search of place-bound companies and effective location policies" Environment and Planning C 25 692-708

Wakeman R, 2003, "Dreaming the new Atlantis: science and the planning of technopolis, 19551985" Osiris 18 255-290 
Ward S, 2002, Planning the Twentieth-Century City (Chichester, UK: Wiley) 